\title{
Hepatitis C Virus with Normal Transaminase Levels
}

\author{
Claudio Puoti \\ Department of Internal Medicine, Marino Hospital, Rome, Italy
}

\author{
Key Words \\ 'Healthy' carriers $\cdot \mathrm{HCV} \cdot$ Interferon • Normal alanine \\ aminotransferase levels
}

\begin{abstract}
Approximately $30 \%$ of patients with chronic HCV infection show persistently normal alanine aminotransferase (PNALT) levels. The majority of these patients have some degree of histological liver damage. Controversies still exist regarding the definition of 'persistent' alanine aminotransferase (ALT) normality, and the natural history and optimal management of chronic hepatitis C with normal ALT. Although patients with HCV infection and normal ALT have been historically excluded from antiviral treatment, with the advent of the new treatment with PEG-interferon plus ribavirin, it has been suggested that the issue of whether or not to treat subjects with PNALT should be re-evaluated, and that antiviral treatment should be useful at least in selected subsets of patients.

Copyright $\odot 2007$ S. Karger AG, Basel
\end{abstract}

During the course of $\mathrm{HCV}$ infection, alanine aminotransferase (ALT) levels could fluctuate, with long periods of biochemical remission [1-4]. It has been suggested that at least two different subsets of HCV carriers exist: patients with wide temporal ALT fluctuations, that could be within the normal range for several months, and true 'biochemically silent' carriers, showing persistently nor-
(C) 2007 S. Karger AG, Basel

$0257-2753 / 07 / 0253-0277 \$ 23.50 / 0$

Fax +4161306 1234

E-Mail karger@karger.ch

www.karger.com
Accessible online at: www.karger.com/ddi mal ALT (PNALT) values. The observation period should not be shorter than 12-18 months, and ALT determinations should be performed every 2-3 months.

The majority of HCV carriers with PNALT have some degree of liver damage on liver biopsy [5-13]. Liver disease is usually minimal/mild and fibrosis is generally absent or minimal $[4-6,8]$. However, the natural history of $\mathrm{HCV}$ carriers with PNALT is probably not always so benign, and the possibility of a more severe evolution of liver disease among patients with PNALT cannot be ruled out. Several studies [7, 10,13-15] reported a significant progression of fibrosis in approximately $20-30 \%$ of the patients with well-defined ALT normality, and the development of HCC in some cases has been described, despite persistent ALT normality $[7,16]$. Sudden worsening of disease with ALT increase and histological deterioration has been described after up to 15 years of follow-up [17].

Historically, patients with PNALT have not been offered antiviral treatment on the belief that carriers with PNALT have milder disease than those with abnormal ALT levels and that IFN might worsen the course of the disease in many patients showing ALT flares during treatment. Given these data, the 1997 NIH Consensus Conference [1] and the EASL Consensus Conference [18] stated that IFN treatment should not be recommended in these subjects.

The introduction of the new combination therapy of PEG-IFN plus ribavirin allowed response rates higher than $50 \%$, with a favorable risk-benefit ratio also in patients with benign or slow progressive disease [19]. In a 
recent international multicenter, randomized study [20] using PEG-interferon- $\alpha_{2 \mathrm{a}}(180 \mu \mathrm{g}$ weekly) plus ribavirin (800 mg daily) for 24 or 48 weeks, the overall sustained response rate was $30 \%$ in patients treated for 24 weeks and 52\% in those treated for 48 weeks [20]. In carriers with genotype $1 \mathrm{~b}$ the response rates were 13 and $40 \%$ respectively, while in those harboring genotype 2 3 response rate ranged from $72 \%$ (24 weeks) to $78 \%$ (48 weeks).

Given the efficacy of the new treatments, which soon became the standard of care for CHC, the 2002 NIH Consensus Development Conference suggested that the issue of whether or not to treat subjects with PNALT should be re-evaluated, and that the issue at hand should be whether or not patients with mild disease should be treated [19]. ALT levels may have less importance in deciding who should be treated [19]. Many other factors might influence the decision to treat, such as the age of the patient, HCV genotype, liver histology, patient's motivation, symptoms, extrahepatic manifestations, comorbid illness.
In agreement with the most recent guidelines and recommendations for the management of hepatitis C [21], it could be suggested that in clinical practice young patients infected with 'easy-to-treat' HCV genotypes (HCV-2 or $\mathrm{HCV}-3$ ), highly motivated and without contraindication may be treated without histological assessment considering the very high rate of SVR that can be achieved with 24 weeks of PEG-IFN plus ribavirin and the excellent safety profile. On the other hand, initiation of antiviral therapy might still be decided mainly on the basis of histological findings by taking a diagnostic liver biopsy in HCV patients with PNALT older than 50 years or infected with 'difficult-to-treat' genotypes, with long-lasting infection or with some relative contraindication. In these clinical settings, treatment should be proposed mainly for cases with significant liver disease (fibrosis stage F2). Finally, a strategy of non-intervention might be preferred in HCV patients with PNALT who are above the age of 60-65 years or have major contraindication to antiviral therapy or are reluctant to be treated.

\section{References}

1 Marcellin P, Lévy S, Erlinger S: Therapy of hepatitis C: patients with normal aminotransferase levels. Hepatology 1997;26(suppl 1):133S-136S.

2 Puoti C, Castellacci R, Montagnese F: Hepatitis $\mathrm{C}$ virus carriers with normal aminotransferase levels: Healthy people or true patients? Digest Liver Dis 2000;32:634-643.

- 3 Puoti C, Magrini A, Stati T, Rigato P, Montagnese F, Rossi P, et al: Clinical, histological and virological features of hepatitis $\mathrm{C}$ virus carriers with persistently normal aminotransferase levels. Hepatology 1997;26:13931398.

-4 Alberti A, Morsica G, Chemello L, Cavalletto D, Noventa F, Pontisso P, et al: Hepatitis C viraemia and liver disease in symptom-free individuals with anti-HCV. Lancet 1992. 340:697-698.

5 Martinot-Peignoux M, Boyer N, Cazals-Hatem D, Bach-Nga P, Gervais A, Le Breton A, et al: Perspective study of anti-hepatitis $\mathrm{C}$ virus-positive patients with persistently normal serum ALT with or without detectable serum HCV RNA. Hepatology 2001;34 1000-1005.

-6 Persico M, Persico E, Suozzo R, Conte S, De Seta M, Sasso FC, et al: Natural history of hepatitis $\mathrm{C}$ virus carriers with persistently normal transaminase levels. Gastroenterology 2000;118:760-764.

-7 Cividini A, Rebucci C, Silini E, Mondelli MU: Is the natural history of HCV carriers with normal aminotransferase levels really benign? Gastroenterology 2001;121:1526-1527.
8 Mathurin P, MoussaliJ, CadranelJF, Thibault V, Charlotte F, Dumouchel P, et al: Slow progression rate of fibrosis in hepatitis $\mathrm{C}$ virus patients with persistently normal alanine transaminase activity. Hepatology 1998;27: 868-872.

-9 Puoti C, Guido M, Mangia A, Persico M, Prati D: Italian Study for the Study of the Liver (AISF) Ad Hoc Committee 'HCV carriers with persistently normal ALT levels'. Position paper. DLD 2003;35:362-369.

10 Puoti C, Castellacci R, Montagnese F, Zaltron S, Stornaiuolo GF, Bergami N, et al: Histological and virological features and followup of hepatitis $C$ virus carriers with normal aminotransferase levels: The Italian Prospective Study of the Asymptomatic C Carriers (ISACC). J Hepatol 2002;37:117-123.

- 11 Prati D, Taioli E, Zanella A, Della Torre E, Butelli S, Del Vecchio E, et al: Updated definitions of healthy ranges for serum alanine aminotransferase. Ann Intern Med 2002; 137:1-10.

12 Puoti C, Stati T, Magrini A: Serum HCV RNA titer does not predict the severity of liver damage in HCV carriers with normal aminotransferase levels. Liver 1999;19:104109.

13 Pradat P, Alberti A, Poynard T, Esteban JI, Weiland O, Marcellin P, et al: Predictive value of ALT levels for histologic findings in chronic hepatitis C: a European Collaborative Study. Hepatology 2002;36:973-977.

14 Hui CK, Belaye T, Montegrande K, Wright TL: A comparison in the progression of liver fibrosis in chronic hepatitis $\mathrm{C}$ between persistently normal and elevated transaminase. J Hepatol 2003;38:511-517.

-15 Puoti C, Bellis L, Martellino F, Durola L, Galossi A, Guarisco R, et al: HCV carriers with 'normal' ALT levels: treat the disease, not the test. J Hepatol 2005;43:534-535.

16 Puoti C, Bellis L, Martellino F, Spilabotti L, Galossi A, Durola L, et al: Occurrence of HCC in a apparently 'healthy' HCV carrier. Eur J Gastroenterol Hepatol 2005; 17:12631264.

17 Rumi MG, De Filippi F, Donato MF, Del Ninno E, Colombo M: Progressive hepatic fibrosis in healthy carriers of hepatitis $C$ virus with a transaminase breakthrough. J Viral Hepatitis 2002;9:71-74.

18 Tassopoulos NC: Treatment in patients with normal ALT levels. J Hepatol 1999;31(suppl 1):193-196.

19 Bacon BR: Treatment of patients with hepatitis $\mathrm{C}$ and normal serum aminotransferase levels. Hepatology 2002;36(suppl 1):S179S184.

20 Zeuzem S, Diago M, Gane E, Reddy R, Pockros $\mathrm{P}$, Farci P, et al: International multicenter, randomized controlled study for treatment of $\mathrm{HCV}$ carriers with persistently normal ALT with PEG-IFN- $\alpha_{2 \mathrm{a}}(40 \mathrm{kDa})$ and ribavirin. Gastroenterology 2004;127:1724-1732.

21 Alberti A: Towards more individualised management of hepatitis $C$ virus patients with initially or persistently normal alanine aminotransferase levels. J Hepatol 2005;42: 266-274. 